\title{
ENTREPRENEUR
}

Jurnal Bisnis Manajemen Dan Kewirausahaan

Program Studi Manajemen Fakultas Ekonomika dan Bisnis Universitas Majalengka

Published every January and July e-ISSN : (Proses), p-ISSN: 2723-1941

Available online https://ejournal.unma.ac.id/index.php/entrepreneur

\section{Pengaruh Shopping Lifestyle dan Positive Emotion \\ Terhadap Impulse Buying \\ (Studi Pada Konsumen UD Putra Tiga Saudara Majalengka)}

\author{
Endah Prihartini \\ Fakultas Ekonomika dan Bisnis Universitas Majalengka \\ Email : endahprihartini581@gmail.com
}

\begin{abstract}
This purpose of this research is to find out the influence of a shopping lifestyle and positive emotion against impulse buying on UD Putra Tiga Saudara Majalengka consumer, buying either partially or simultaneously. This research is a survey research using descriptive and verification approaches. The sample of this research is 150 people. They are concumer of UD Putra Tiga Saudara Majalengka. Data collectionof this research used questionnaire method. Likert measurement scale is used on this research. The analysis of data processing is used SPSS 21. Data analysis were performed using test of validity, reliability, the test of the classic, coefficient determination analysis and hypothesis testing using $t$ test and $F$ test. The results obtained of shopping lifestyle, positive emotion, and with impulse buying in UD Putra Tiga Saudara Majalengka including high category. As for influence of shopping lifestyle and positive emoton of impulse buying partially and simultaneously have a positive and significant effect.

Keywords:

shopping lifestyle, positive emotion, impulse buying
\end{abstract}




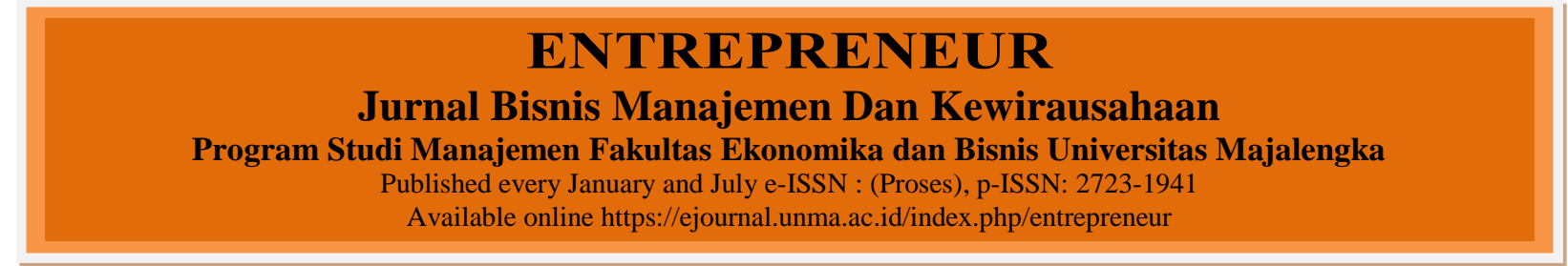

\section{PENDAHULUAN}

Dewasa ini perkembangan ekonomi di Indonesia meningkat sangat cepat, salah satu penyebab meningkatnya perekonomian di Indonesia seiring berjalan atau adanya globalisasi ekonomi. Perkembangan ritel atau pasar eceran yang begitu pesat, berdampak semakin tingginya persaingan memperebutkan pangsa pasar pada dunia usaha saat ini. Perusahaan yang ingin berhasil dalam persaingan pada era milenium harus memiliki strategi perusahaan yang dapat memahami perilaku konsumen. Perusahaan yang baik adalah yang memahami betul siapa konsumennya dan bagaimana mereka berperilaku.

Mangkunegara

(2009:4), perilaku konsumen adalah tindakantindakan yang dilakukan oleh individu atau organisasi yang berhubungan dengan proses pengambilan keputusan dalam mendapatkan, menggunakan barang-barang atau jasa ekonomi dapat dipengaruhi lingkungannya namun adakala pembelian dilakukan begitu saja ketika konsumen melihat suatu produk.

Impulse buying yang dilakukan oleh konsumen bukanlah hal yang baru dalam pemasaran, namun penjelasan mengapa hal tersebut bisa terjadi belum banyak diketahui oleh pebisnis. Oleh karena itulah pebisnis harus mempelajari hal-hal apa saja yang dapat memicu terjadinya impulse buying. Strategi ini dilakukan agar pebisnis dapat melakukan strategi-strategi pemasaran selanjutnya untuk menjaring lebih banyak konsumen sehingga akan mendatangkan omzet yang banyak bagi perusahaan.

Menurut Beatty \& Ferrel dalam (Park et. Al., 2006) emosi sangat mempengaruhi tindakan impulse buying. Emosi merupakan keadaan testimulasi dari organisme, yang meliputi perubahan-perubahan, termasuk perubahan prilaku Chaplin dalam penelitian yang dilakukan oleh Jondry Hrtharie (2012), konsumen yang mempunyai mood positif akan lebih kondusif untuk melakukan pembelian implusif daripada konsumen yang suasana hatinya negatif. Emosi yang merasa senang dan bangga ketika berbelanja dapat mempengaruhi pembelian implusif. Tirmizi et al. dalam Mega Usvita (2015:72) positive emotion sendiri didefinisikan sebagai suasana hati yang mempengaruhi dan menentukan intensitas pengambilan keputusan konsumen.

Rachmawati (2009) menyatakan bahwa ketika seseorang melakukan impulse buying bisa dipengaruhi oleh beberapa faktor, yaitu hedonic shopping value, shopping lifestyle, dan positive emotion. Betty Jackson dalam Edwin Japarianto dan Sugiono Sugiharto (2011: 33) mengatakan bahwa shopping lifestyle merupakan ekspresi tentang lifestyle dalam berbelanja yang mencerminkan perbedaan status sosial. Konsumen akan rela mengorbankan sesuatu demi mendapatkan produk yang mereka inginkan dan mereka senangi.

Objek penelitian ini dilakukan di UD Putra Tiga Saudara Majalengka. UD Putra Tiga Saudara merupakan salah satu retail dan grosir yang bergerak dibidang bisnis fashion anakanak sampai dewasa, menyediakan peralatan bayi, kosmetik, tas, dan boneka. UD Putra Tiga Saudara dibangun secara bertahap dan mengalami kemajuan dalam hal perluasan toko dan lahan parkir yang 


\section{ENTREPRENEUR}

Jurnal Bisnis Manajemen Dan Kewirausahaan

Program Studi Manajemen Fakultas Ekonomika dan Bisnis Universitas Majalengka Published every January and July e-ISSN : (Proses), p-ISSN: 2723-1941 Available online https://ejournal.unma.ac.id/index.php/entrepreneur

membuat konsumen lebih nyaman berbelanja di UD Putra Tiga Saudara Majalengka.

Berdasarkan hasil pra survey pada konsumen UD Putra Tiga Saudara Majalengka hanya ada $30 \%$ konsumen yang merencanakan apa yang akan di beli dan tidak membeli item tambahan yang akan dibeli, sebanyak 30\% konsumen merencanakan apa yang akan dibeli tetapi membeli item tambahan tanpa direncanakan sebelumnya, dan sisanya $40 \%$ tidak merencanakan apa yang akan mereka beli. Dan hanya $40 \%$ responden menyatakan lebih suka berbelanja tanpa melakukan perencanaan terlebih dahulu. Maka dapat disimpulkan bahwa sebagian besar konsumen UD Putra Tiga Saudara melakukan impulse buying.

Konsumen yang melakukan perencanaan dan tidak membeli item tambahan diluar yang direncanakan biasanya memiliki waktu luang yang terbatas dan tidak membawa uang lebih untuk berbelanja, selain itu mereka mendisiplinkan diri mereka sehingga terbiasa untuk tidak membeli item tambahan. Hal tersebut berbanding terbalik dengan konsumen yang melakukan perencanaan sebelum berbelanja. Mereka menganggap berbelanja adalah hal yang menyenangkan dan bisa mengisi waktu luang, sambil belanja untuk pemenuhan kebutuhan. Sedangkan konsumen yang melakukan perencanaan sebelum berbelanja tetapi juga membeli item tambahan diluar perencanaan seringkali terstimulus oleh diskon atau barang yang mereka suka di dalam toko.

Berdasarkan fenomena tersebut, penulis tertarik untuk melakukan penelitian dengan judul "PENGARUH
SHOPPING LIFESTYLE DAN

POSITIVE EMOTION TERHADAP IMPULSE BUYING (Studi Pada Konsumen UD Putra Tiga Saudara Majalengka)".

\section{Rumusan Masalah}

Berdasarkan latar belakang yang telah dikemukakan sebelumnya, maka rumusan masalah dalam penelitian ini bagaimana pengaruh shopping lifestyle dan positive emotion terhadap impulse buying di UD Putra Tiga Saudara Majalengka secara parsial maupun simultan.

\section{Tujuan Penelitian}

Berdasarkan rumusan masalah, maka tujuan dari penelitian ini adalah untuk mengetahui bagaimana pengaruh shopping lifestyle dan positive emotion terhadap impulse buying di UD Putra Tiga Saudara Majalengka.

\section{KERANGKA TEORITIS DAN HIPOTESIS}

\section{Hubungan Shopping Life Style dengan Impulse Buying}

Menurut Rahmawati (2009) menyatakan bahwa ketika seseorang melakukan impulse buying bisa dipengaruhi oleh beberapa faktor, yaitu hedonic shopping value, shopping lifestyle dan positive emotion. Berdasarkan hasil penelitian Japarianto \& Sugiharto (2011) dan Lumintang (2012) shopping lifestyle perpengaruh signifikan terhadap impulse buying .

\section{Hubungan Positive Emotion dengan Impulse Buying}

Hubungan positive emotion dan impulse buying sebagaimana dinyatakan oleh Sherman, et al., (1997) dalam 


\section{ENTREPRENEUR}

\section{Jurnal Bisnis Manajemen Dan Kewirausahaan}

\section{Program Studi Manajemen Fakultas Ekonomika dan Bisnis Universitas Majalengka} Published every January and July e-ISSN : (Proses), p-ISSN: 2723-1941 Available online https://ejournal.unma.ac.id/index.php/entrepreneur

Pattipeilohy, et al., (2013, p. 38) yang menjelaskan bahwa positive emotion bisa menjadi mediasi terjadinya impulse buying "positive emotion can act as a mediator for impulse buying." Sedangkan Donovan and Rositer (1982) dalam Pattipeilohy, et al., (2013, p. 38) menjelaskan bahwa impulse buying seringkali terjadi ketika seseorang menunjukan positive emotion yang tinggi sehingga berperilaku lebih hedonis ketika berbelanja "an impulse buyer often shows greater positive emotions, and spends more money when shopping." Hasil penelitian Aryadini (2012) juga menunjukan bahwa emosi positif merupakan variabel independen yang paling berpengaruh terhadap impulse buying.

\section{Hubungan Shopping Lifestyle dan Positive Emotion dengan Impulse Buying}

Shopping

Lifestyle mencerminkan pilihan seseorang dalam menghabiskan waktu dan uang. Dengan ketersediaan waktu konsumen akan memiliki banyak waktu untuk berbelanja dan dengan uang konsumen akan memiliki daya beli yang tinggi. Hal tersebut tentu berkaitan dengan keterlibatan konsumen terhadap suatu produk yang juga mempengaruhi terjadinya impulse buying. Menurut hasil penelitian yang dilakukan Usvita (2015), shopping lifestyle dan positive emotion berpengaruh secara bersamasama terhadap impulse buying.

\section{Kerangka Pemikiran}

Dune \& Lusch dalam Sinai Ariani (2017: 35) menyatakan bahwa $70 \%$ pembelian yang terjadi di pasar modern atau ritel ternyata merupakan pembelian imulsif (impulse buying). Banyak kegiatan belanja sehari-hari yang tidak di dasari oleh pertimbangan yang matang atau yang biasa disebut dengan impulse buying. Hal-hal yang dapat mempengaruhi terjadinya impulse buying diantaranya faktor eksternal yaitu respon lingkungan belanja, dalam hal ini emosi positif Samuel, (2005), dan faktor shopping lifestyle Japarianto (2011).

Shopping lifestyle adalah cara seseorang untuk mengalokasikan waktu dan uang untuk berbagai produk, layanan, teknologi, hiburan, pendidikan, sikap dan pendapat mereka tentang dunia dimana mereka tinggal. Dalam penelitian ini, shopping lifestyle menggunakan dimensi dari Suwarman (2003), yaitu activities, interest, dan opinion.

Positive emotion dapat ditimbulkan oleh suasana hati individu yang sudah ada sebelumnya, disposisi afektif, dan reaksi terhadap lingkungan (misalnya item yang diinginkan, promosi penjualan). Rook dan Gardner (1993) positive emotion didefinisikan sebagai mood atau perasaan seperti jatuh cinta, sempurna, gembira, ingin memiliki dan antusias. Dalam penelitian ini, dimensi yang digunakan bersumber dari Mehrabian dan Russel dalam Japarianto \& Darma (2014). Dimensidimensi tersebut yaitu pleasure, arousal dan dominance.

Menurut Beatty \& Ferrel dalam Park et. Al., (2006) emosi sangat mempengaruhi tindakan impulse buying. Impulse buying adalah suatu kegiatan pembelian barang dan atau jasa yang tidak direncanakan sebelumnya, dan dengan sedikit atau tanpa pertimbangan mendalam, serta kurang 


\section{ENTREPRENEUR}

Jurnal Bisnis Manajemen Dan Kewirausahaan

Program Studi Manajemen Fakultas Ekonomika dan Bisnis Universitas Majalengka Published every January and July e-ISSN : (Proses), p-ISSN: 2723-1941 Available online https://ejournal.unma.ac.id/index.php/entrepreneur

memikirkan akibat atau manfaat produk, yang mana keputusan pembeliannya dilakukan ketika konsumen berada di dalam toko. Dalam penelitian ini, dimensi-dimensi yang digunakan dikemukakan oleh Beatty and Ferrel dalam Buendicho, yaitu Urge to Purchase, Positive Affect, In-Store Browsing, Shopping Enjoyment, Time Available, Money Available, dan Impulse Buying Tendecy.

Kerangka pemikiran diatas dapat digambarkan dalam paradigma penelitian berikut :

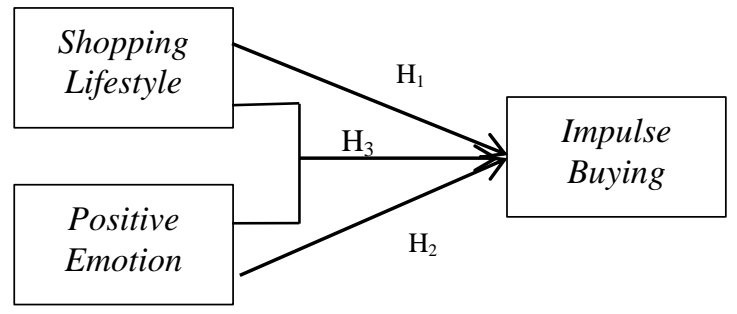

Gambar 1

Paradigma Penelitian

\section{Hipotesis}

$\mathrm{H}_{1}=$ Terdapat pengaruh yang signifikan antara shopping lifestyle terhadap impulse buying.

$\mathrm{H}_{2}=$ Terdapat pengaruh yang signifikan antara positive emotion terhadap impulse buying.

$\mathrm{H}_{3}=$ Terdapat pengaruh yang signifikan antara shopping lifestyle dan positive emotion terhadap impulse buying.

\section{Metode Penelitian}

Dalam Penelitian ini metode yang digunakan adalah metode survey dengan pendekatan deskriftif dan verifikatif. Adapun yang menjadi populasi dalam penelitian ini adalah konsumen Usaha Dagang (UD) Putra Tiga Saudara Majalengka yang tidak terhingga sehingga tidak bisa dihitung jumlah pastinya. Teknik pengambilan sampel yang digunakan dalam penelitian adalah Non Probability sampling dengan accicidental sampling dengan jumlah sampel 150 konsumen.
Jenis data yang diguanakn dalam penelitian ini adalah data kuantitatif. Metode pengumpulan data dengan menggunakan kuesioner. Proses pengolahan data menggunakan bantuan program SPPS 21. Sebelum kuesioner disebar, kuesioner di uji terlebih dahulu kesahihan dan kehandalannya melalui uji validitas uji reliabilitas. Analisis antara variabel bebas dan variabel terikat diuji dengan menggunakan uji asumsi klasik, analisis regresi berganda, analisis koefisien determinasi, pengujian hipotesis menggunakan uji parsial (uji t) dan uji simultan (uji F).

Variabel dalam penelitian ini adalah :

1. Shopping Lifestyle $\left(\mathrm{X}_{1}\right)$. Menurut Levy dalam Anggi Mita Wijaya (2016: 189) Shopping lifestyle adalah gaya hidup yang mengacu pada bagaimana seseorang hidup, bagaimana mereka menghabiskan waktu, uang, kegiatan pembelian yang dilakukan, sikap dan pendapat mereka tentang dunia dimana 


\section{ENTREPRENEUR}

\section{Jurnal Bisnis Manajemen Dan Kewirausahaan}

\section{Program Studi Manajemen Fakultas Ekonomika dan Bisnis Universitas Majalengka} Published every January and July e-ISSN : (Proses), p-ISSN: 2723-1941 Available online https://ejournal.unma.ac.id/index.php/entrepreneur

mereka tinggal. Shopping Lifestyle dalam penelitian ini diukur melalui dimensi : Kegiatan (activities), Minat (interest), Opini (opinion)

2. Posiive Emotion $\left(\mathrm{X}_{2}\right)$

Baron dan Byrne Pattipeilohy, et al., (2013, p. 38) menjelaskan

involvement." Dijelaskan bahwa positive emotion didefinisikan sebagai pengaruh positif yang mendorong seseorang memiliki antusiasme, aktif, dan waspada dan emosi positif menyebabkan seseorang merasa memiliki energi yang besar, konsentrasi penuh, dan merasa senang. Positive Emotion dalam Penelitian ini diukur dengan dimensi menurut Mehrabian \& Russel (Japarianto \& Darma, 2014) yaitu : Kesenangan (pleasure), Antusias (araousal), Pengendalian (dominance)

3. Impulse Buying (Y)

Coley dalam Anggi Mita Wijaya (2016: 190) Impulse buying didefinisikan sebagai "tindakan membeli yang sebelumnya tidak di akui secara sadar sebagai hasil dari suatu pertimbangan atau niat membeli yang terbentuk sebelum memasuki toko". Impulse buying

Tabel 1

Usia Responden

\begin{tabular}{|c|c|c|}
\hline Usia & Jumlah & Persentase (\%) \\
\hline 16-25 tahun & 67 & 44,66 \\
\hline 26-40 tahun & 49 & 32,66 \\
\hline 41-55 tahun & 31 & 20,66 \\
\hline$>55$ tahun & 3 & 2,02 \\
\hline Total & 150 & 100 \\
\hline
\end{tabular}

Sumber: Data kuesioner yang telah diolah

Pada tabel dapat diketahui bahwa data usia responden yang yang diteliti terdiri atas 67 orang dengan
"Positive feeling can be conceptualized as a positive influence, which reflects the extent to which a person feels enthusiastic, active, and alert. It a condition of high energy, full concentration, and fun

dalam penelitian ini diukur dengan dimensi Menurut Beatty dan Ferrel, dalam Buendicho (2003) yaitu sebagai berikut : Desakan untuk belanja (Urge to Purchase), Emosi Positif (Positive Affect), Melihatlihat Toko (In-Store Browsing), Kesenangan Berbelanja (Shopping Enjoyment), Ketersediaan Waktu (Time Available), Ketersediaan Uang (Money Available), Kecenderungan Pembelian Impulsif (Impulse Buying Tendency)

\section{Hasil Penelitian \\ Identitas Responden \\ Karakteristik Berdasarkan Usia}

Dari penelitian terhadap 100 orang responden mengenai usia dapat dilihat pada tabel berikut: rentang usia 16 sampai 25 tahun (44,66\%), 49 orang dengan rentang usia 26 sampai 40 tahun (32,66\%), 31 orang dengan rentang usia 41 sampai 55 tahun 


\section{ENTREPRENEUR}

\section{Jurnal Bisnis Manajemen Dan Kewirausahaan}

\section{Program Studi Manajemen Fakultas Ekonomika dan Bisnis Universitas Majalengka} Published every January and July e-ISSN : (Proses), p-ISSN: 2723-1941 Available online https://ejournal.unma.ac.id/index.php/entrepreneur

$(20,66 \%)$, dan 3 orang dengan rentang usia lebih dari 55 tahun $(2,02 \%)$. Dari hasil pengamatan menunjukan bahwa konsumen UD Putra Tiga Saudara Majalengka mayoritas berusia 16 sampai 25 tahun, dimana usia tersebut merupakan usia yang labil sehingga pembelian dilakukan berdasarkan keinginan sendiri yang tiba-tiba.

\section{Karakteristik Pekerjaan}

Dari penelitian terhadap 100 orang responden mengenai pekerjaan dapat dilihat pada tabel berikut:

Tabel 2

Pekerjaan Responden

\begin{tabular}{|l|c|c|}
\hline \multicolumn{1}{|c|}{ Pekerjaan } & Jumlah & Persentase (\%) \\
\hline Pelajar/Mahasiswa & 61 & 40,66 \\
\hline PNS/TNI/POLRI & 14 & 14,33 \\
\hline Pegawai Swasta & 10 & 6,66 \\
\hline Ibu Rumah Tangga & 36 & 24 \\
\hline Wiraswasta & 29 & 19,33 \\
\hline Total & 150 & 100 \\
\hline
\end{tabular}

Sumber: Data kuesioner yang telah diolah

Pada tabel 4.2 dapat diketahui bahwa data pekerjaan responden yang yang diteliti terdiri atas $61(44,66 \%)$ orang adalah pelajar/mahasiswa, 14 $(14,33 \%) \quad$ orang adalah PNS/TNI/POLRI, $10(6,66 \%)$ orang adalah pegawai swasta, 36 (24\%) adalah Ibu rumah tangga, dan 29 (19,33\%) orang adalah Wiraswasta. Dari hasil pengamatan menunjukan bahwa konsumen Toko UD Putra Tiga Saudara Majalengka mayoritas berstatus Pelajar/Mahasiswa, karena Toko UD Putra Tiga Saudara Majalengka yang dilihat dari segi harga relatif murah sehingga menarik pelajar/mahasiswa untuk berbelanja.

\section{Pengujian Instrument Uji Validitas}

Uji validitas dalam penelitian ini dilakukan dengan 26 pernyataan yang terdiri dari 6 pernyataan untuk variabel shopping lifestyle (X1), 6 pernyataan untuk variabel positive emotion (X2), dan 14 pernyataan untuk variabel impulse buying (Y). Perhitungan uji validitas dalam penelitian ini menggunakan SPSS versi 21 dan hasil uji validitas untuk masing-masing variabel dijelaskan dalam tabel berikut:

\section{Tabel 3}

Hasil Uji Validitas

Variabel Shopping Lifestyle $\left(\mathrm{X}_{1}\right)$

\begin{tabular}{|c|c|c|c|}
\hline $\begin{array}{c}\text { No. Item } \\
\text { Pernyataan }\end{array}$ & $\mathrm{r}_{\text {hitung }}$ & $\begin{array}{c}\mathrm{r}_{\text {tabel }} \\
(\mathrm{a}=5 \%)\end{array}$ & Ket \\
\hline Pernyataan 1 & 0,516 & 0,159 & Valid \\
\hline Pernyataan 2 & 0,377 & 0,159 & Valid \\
\hline Pernyataan 3 & 0,365 & 0,159 & Valid \\
\hline Pernyataan 4 & 0,345 & 0,159 & Valid \\
\hline Pernyataan 5 & 0,441 & 0,159 & Valid \\
\hline Pernyataan 6 & 0,394 & 0,159 & Valid \\
\hline
\end{tabular}

Sumber: Output SPSS Versi 21 


\section{ENTREPRENEUR}

\section{Jurnal Bisnis Manajemen Dan Kewirausahaan}

Program Studi Manajemen Fakultas Ekonomika dan Bisnis Universitas Majalengka Published every January and July e-ISSN : (Proses), p-ISSN: 2723-1941 Available online https://ejournal.unma.ac.id/index.php/entrepreneur

Berdasarkan hasil uji validitas terhadap variabel shopping lifestyle (X1), menunjukan bahwa $\mathrm{r}_{\text {hitung }}$ untuk 6 pernyataan lebih besar dari $r_{\text {tabel }}$ pada

\section{Tabel 4}

Hasil Uji Validitas

Variabel Positive Emotion $\left(\mathrm{X}_{2}\right)$

\begin{tabular}{|c|c|c|c|}
\hline $\begin{array}{c}\text { No. Item } \\
\text { Pernyataan }\end{array}$ & $\mathrm{r}_{\text {hitung }}$ & $\begin{array}{c}\mathrm{r}_{\text {tabel }} \\
(\mathrm{a}=5 \%)\end{array}$ & Ket \\
\hline Pernyataan 1 & 0,518 & 0,159 & Valid \\
\hline Pernyataan 2 & 0,454 & 0,159 & Valid \\
\hline Pernyataan 3 & 0,484 & 0,159 & Valid \\
\hline Pernyataan 4 & 0,544 & 0,159 & Valid \\
\hline Pernyataan 5 & 0,485 & 0,159 & Valid \\
\hline Pernyataan 6 & 0,431 & 0,159 & Valid \\
\hline
\end{tabular}

\section{Sumber: Output SPSS Versi 21}

Berdasarkan hasil uji validitas terhadap variabel positive emotion (X2), menunjukan bahwa $\mathrm{r}_{\text {hitung }}$ untuk 6 pernyataan lebih besar dari $r_{\text {tabel }}$ pada

\section{Tabel 5}

Hasil Uji Validitas

Variabel Impulse Buying (Y)

\begin{tabular}{|c|c|c|c|}
\hline No Item Pernyataan & $\mathrm{r}_{\text {hitung }}$ & $\begin{array}{c}\mathrm{r}_{\text {tabel }} \\
(\mathrm{a}=5 \%)\end{array}$ & Ket \\
\hline Pernyataan 1 & 0,403 & 0,159 & Valid \\
\hline Pernyataan 2 & 0,360 & 0,159 & Valid \\
\hline Pernyataan 3 & 0,496 & 0,159 & Valid \\
\hline Pernyataan 4 & 0,455 & 0,159 & Valid \\
\hline Pernyataan 5 & 0,417 & 0,159 & Valid \\
\hline Pernyataan 6 & 0,413 & 0,159 & Valid \\
\hline Pernyataan 7 & 0,492 & 0,159 & Valid \\
\hline Pernyataan 8 & 0,532 & 0,159 & Valid \\
\hline Pernyataan 9 & 0,654 & 0,159 & Valid \\
\hline Pernyataan 10 & 0,525 & 0,159 & Valid \\
\hline Pernyataan 11 & 0,366 & 0,159 & Valid \\
\hline Pernyataan 12 & 0,437 & 0,159 & Valid \\
\hline Pernyataan 13 & 0,439 & 0,159 & Valid \\
\hline Pernyataan 14 & 0,404 & 0,159 & Valid \\
\hline
\end{tabular}

Sumber: Output SPSS Versi 21

Berdasarkan hasil uji validitas terhadap variabel impulse buying (Y), menunjukan bahwa $r_{\text {hitung }}$ untuk 14 pernyataan lebih besar dari $r_{\text {tabel }}$ pada taraf signifikan 5\% yakni sebesar 0,159. Sehingga dapat disimpulkan bahwa seluruh butir pernyataan tersebut valid. taraf signifikan $5 \%$ yakni sebesar 0,159 . Sehingga dapat disimpulkan bahwa seluruh butir pernyataan tersebut valid. taraf signifikan 5\% yakni sebesar 0,159. Sehingga dapat disimpulkan bahwa seluruh butir pernyataan tersebut valid. 


\section{ENTREPRENEUR}

Jurnal Bisnis Manajemen Dan Kewirausahaan

Program Studi Manajemen Fakultas Ekonomika dan Bisnis Universitas Majalengka Published every January and July e-ISSN : (Proses), p-ISSN: 2723-1941 Available online https://ejournal.unma.ac.id/index.php/entrepreneur

yang sama. Instrumen dikatakan reliabel apabila nilai cronbach alpha lebih besar dari 0,60 (Imam Ghazali 2009:46).
Hasil uji reliabilitas dalam penelitian ini dapat dilihat pada tabel berikut:

\section{Tabel 6}

\section{Hasil Uji Reliabilitas}

\begin{tabular}{|c|c|c|c|c|}
\hline Variabel & $\begin{array}{c}\text { Total } \\
\text { Item } \\
\text { Pernyataan }\end{array}$ & $\begin{array}{c}\text { Nilai } \\
\text { Cronbach's } \\
\text { Alpha }\end{array}$ & $\begin{array}{c}\text { Nilai } \\
\text { Kritis }\end{array}$ & Ket \\
\hline $\begin{array}{c}\text { Shopping } \\
\text { Lifestyle }\end{array}$ & 6 & 0,675 & 0,60 & Reliabel \\
\hline $\begin{array}{c}\text { Positive } \\
\text { Emotion }\end{array}$ & 6 & 0,734 & 0,60 & Reliabel \\
\hline $\begin{array}{c}\text { Impulse } \\
\text { Buying }\end{array}$ & 14 & 0,825 & 0,60 & Reliabel \\
\hline
\end{tabular}

Sumber: Output SPSS Versi 21

Berdasarkan hasil uji reliabilitas pada masing-masing variabel menunjukan nilai Cronbach Alpha yang lebih besar dibandingkan dengan nilai kritis, yakni 0,675, 0,734 dan 0,825 lebih besar dari 0,60. Ini berarti bahwa seluruh pernyataan dalam kuesioner dinyatakan reliabel.

\section{Pembahasan}

Analisis Deskriptif

Shopping Life Style

Berdasarkan hasil rekapitulasi tanggapan responden terhadap variabel shopping lifestyle diperoleh total skor untuk seluruh item pernyataan sebesar 3.076. Konsumen lebih dominan menyatakan setuju dari enam item pernyataan yang diajukan. Hal ini menunjukan bahwa hasil penelitian mengenai shopping lifestyle konsumen UD Putra Tiga Saudara Majalengka dinyatakan tinggi menurut konsumen.

\section{Positive Emotion}

Berdasarkan hasil rekapitulasi tanggapan responden terhadap variabel positive emotion yang tertera pada tabel 4.9, diperoleh total skor untuk seluruh item pernyataan sebesar 3.206. Konsumen lebih dominan menyatakan setuju dari enam item pernyataan yang diajukan. Hal ini menunjukan bahwa hasil penelitian mengenai positive emotion konsumen UD Putra Tiga Saudara Majalengka dinyatakan tinggi menurut konsumen.

\section{Impulse Buying}

Berdasarkan hasil rekapitulasi tanggapan responden terhadap variabel impulse buying diperoleh total skor untuk seluruh item pernyataan sebesar 6.953. Konsumen lebih dominan menyatakan setuju dari empat belas item pernyataan yang diajukan. Hal ini menunjukan bahwa hasil penelitian mengenai impulse buying konsumen UD Putra Tiga Saudara Majalengka dinyatakan tinggi menurut konsumen.

\section{Analisis Verifikatif Uji Asumsi Klasik}

\section{Uji Normalitas Data}

Uji normalitas dalam penelitian ini dilakukan dengan uji KolmogrovSmirnov dan grafik histogram. Tabel uji Kolmogrov-Smirnov, dan grafik histogram dapat dilihat sebagai berikut : 


\section{ENTREPRENEUR}

\section{Jurnal Bisnis Manajemen Dan Kewirausahaan}

Program Studi Manajemen Fakultas Ekonomika dan Bisnis Universitas Majalengka Published every January and July e-ISSN : (Proses), p-ISSN: 2723-1941 Available online https://ejournal.unma.ac.id/index.php/entrepreneur

\section{Tabel 7}

Hasil Uji Normalitas Data One-Sample Kolmogorov-Smirnov Test

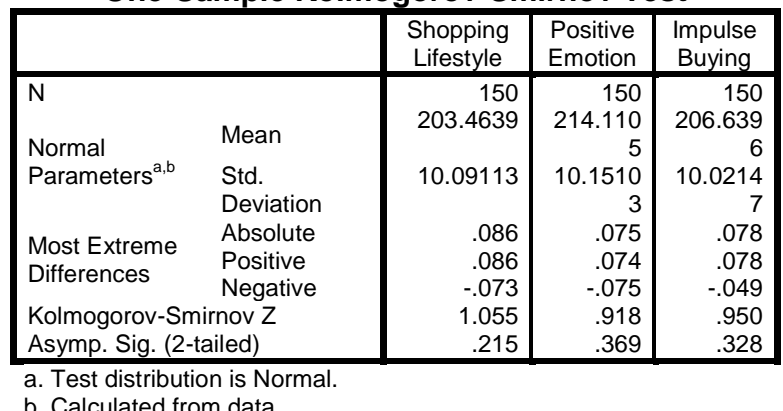

Berdasarkan tabel tersebut dapat diketahui bahwa nilai dari asymp. Sig. (2-tailed) Shopping Lifestyle adalah 0,215, Positive Emotion adalah 0,369, dan Impulse Buying adalah 0,328 menunjukkan nilai signifikansi yang lebih besar dari $\alpha=0,05$. Sehingga dapat disimpulkan bahwa data dalam penelitian ini memiliki distribusi normal.

\section{Uji Multikolinieritas}

Pengujian ini dilakukan untuk melihat apakah pada model regresi ditemukan adanya korelasi antar variabel bebas. Menurut Ghozali (2015) pada umunya jika VIF > 10, maka variabel tersebut mempunyai persoalan multikolinearitas dengan variabel bebas lainnya

Tabel 8

Hasil Uji Multikolinearitas

Coefficients $^{\mathrm{a}}$

\begin{tabular}{|c|c|c|c|c|c|c|c|c|}
\hline & \multirow{2}{*}{ Model } & \multicolumn{2}{|c|}{ Unstandardized Coefficients } & \multirow{2}{*}{$\begin{array}{c}\text { Standardized } \\
\text { Coefficients }\end{array}$} & \multirow{2}{*}{$\mathrm{T}$} & \multirow{2}{*}{ Sig. } & \multicolumn{2}{|c|}{$\begin{array}{c}\text { Collinearity } \\
\text { Statistics }\end{array}$} \\
\hline & & B & Std. Error & & & & $\begin{array}{c}\text { Toleran } \\
\text { ce }\end{array}$ & VIF \\
\hline \multirow{3}{*}{1} & (Constant) & 152,805 & 19.560 & & 7.812 &, 000 & & \\
\hline & $\begin{array}{l}\text { Shopping } \\
\text { Lifestyle }\end{array}$ &, 205 &, 189 &, 207 & 2.320 & ,002 &, 808 & 1,238 \\
\hline & Positive Emotion & 156 & ,188 & 157 & 2.639 & ,004 & 808 & 1,238 \\
\hline
\end{tabular}

Tabel diatas menunjukkan bahwa nilai tolerance dari variabel Shopping Lifestyle yakni 0,808 dan Positive Emotion 0,808 lebih besar dari 0,10. Sementara itu nilai VIF dari variabel Shopping Lifestyle yakni 1,238 dan variabel Positive Emotion 1,238 lebih kecil dari 10,00. Sehingga dapat disimpulkan tidak terjadi multikolinearitas.

\section{Uji Autokorelasi}

Pengujian ini dilakukan untuk menguji suatu model apakah antara variabel pengganggu masing-masing variabel bebas saling mempengaruhi. Adapun hasil pengujian autokorelasi adalah sebagai berikut: 


\section{ENTREPRENEUR}

\section{Jurnal Bisnis Manajemen Dan Kewirausahaan}

\section{Program Studi Manajemen Fakultas Ekonomika dan Bisnis Universitas Majalengka}

Published every January and July e-ISSN : (Proses), p-ISSN: 2723-1941

Available online https://ejournal.unma.ac.id/index.php/entrepreneur

\section{Tabel 9}

Hasil Uji Autokorelasi

Model Summary ${ }^{\mathrm{b}}$

\begin{tabular}{|l|c|c|c|c|c|}
\hline Model & $\mathrm{R}$ & $\begin{array}{c}\mathrm{R} \\
\text { Squar } \\
\mathrm{e}\end{array}$ & $\begin{array}{c}\text { Adjus } \\
\text { ted R } \\
\text { Squar } \\
\mathrm{e}\end{array}$ & $\begin{array}{c}\text { Std. Error } \\
\text { of the } \\
\text { Estimate }\end{array}$ & $\begin{array}{c}\text { Durbin- } \\
\text { Watson }\end{array}$ \\
\hline 1 & $.437^{\mathrm{a}}$ & .190 & .144 & 9.80103 & 1.989 \\
\hline
\end{tabular}

a. Predictors: (Constant), Positive Emotion,

Shopping Lifestyle

b. Dependent Variable: Impulse Buying

Dari hasil pengujian dengan menggunakan uji Durbin-Watson atas diperoleh angka sebesar 1,989. Selanjutnya bandingkan nilai ini dengan nilai table signifikan 5\%, jumlah sampel $(n)=150$ dan variable independent $(\mathrm{k})=$ 2, maka diperoleh nilai $\mathrm{DU}=1,7602$ (terdapat pada tabel Durbin Waston).

Nilai DW 1,989 lebih besar dari nilai batas atas (DU) yakni 1,7602 dan kurang dari (4-du) 4-1,7602 = 2,239. Sehingga dapat disimpulkan tidak terdapat autokorelasi.

\section{Uji Heteroskedastisitas}

Uji Heterokedasitas bertujuan untuk menguji apakah dalam model regresi terjadi ketidak samaan varians.
Berdasarkan grafik scatterplot menunjukkan bahwa terdapat pola yang jelas serta titik - titik menyebar secara acak serta baik diatas maupun dibawah angka 0 pada sumbu $Y$, hal ini dapat disimpulkan bahwa tidak terjadi Heteroskedastisitas pada model regresi.

\section{Analisis Regresi}

Hasil pengolahan analisis regresi berganda dengan menggunakan software SPSS 21 adalah sebagai berikut:

\section{Tabel 10}

Hasil Analisis Regresi Linier Berganda Coefficients $^{\mathrm{a}}$

\begin{tabular}{|c|c|c|c|c|c|c|}
\hline \multirow{2}{*}{ Model } & \multicolumn{2}{|c|}{ Unstandardized Coefficients } & $\begin{array}{l}\text { Standardized } \\
\text { Coefficients }\end{array}$ & \multirow{2}{*}{$\mathrm{t}$} & \multirow{2}{*}{ Sig. } & Collinearity Statistics \\
\hline & B & Std. Error & Beta & & & Tolerance \\
\hline (Constant) & 152,80 & 19.56 & & 7.812 & ,000 & \\
\hline & 205 & 189 & 207 & 2.320 & ,002 & 808 \\
\hline & ,156 & 188 & ,157 & 2.639 & ,004 & 808 \\
\hline $\begin{array}{l}\text { Positive } \\
\text { Emotion }\end{array}$ & & & & & & \\
\hline
\end{tabular}

b. Dependent Variable: Impulse Buying

Sumber : Output SPSS Versi 21, 2018 


\section{ENTREPRENEUR}

\section{Jurnal Bisnis Manajemen Dan Kewirausahaan}

Program Studi Manajemen Fakultas Ekonomika dan Bisnis Universitas Majalengka Published every January and July e-ISSN : (Proses), p-ISSN: 2723-1941 Available online https://ejournal.unma.ac.id/index.php/entrepreneur

Dari tabel menunjukan bahwa persamaan regresi linear berganda yang diperoleh dari hasil analisis yaitu $\mathrm{Y}=$ $152.805+0,205_{\mathrm{x} 1}+0,156_{\mathrm{x} 2}+\mathrm{e}$ maka dari persamaan di atas dapat diartikan sebagai berikut : Konstanta $(\alpha)$ dalam regresi sebesar 152,.805 dan bertanda positif artinya jika semua variabel bebas (shopping lifestyle dan positive emotion) memiliki nilai tidak ada maka variabel terikat (impulse buying) akan tetap ada. Koefisien regresi shopping lifestyle sebesar 0.205 dan bertanda positif, artinya jika shopping lifestyle tinggi maka impulse buying akan tinggi. jika variabel shopping lifestyle rendah maka akan mengalami penurunan terhadap nilai impulse buying. Koefisien regresi positive emotion 0,156 dan bertanda positif, artinya variabel positive emotion tinggi maka akan mengalami peningkatan terhadap nilai impulse buying dan jika variabel positive emotion rendah maka akan mengalami penurunan terhadap impulse buying. Nilai residual $(\varepsilon)$ artinya eror bahwa memprediksi data sampel yang dilakukan oleh peneliti.

\section{Analisis Koefisien Determinasi}

Koefisien determinasi digunakan untuk mengetahui seberapa besar persentase pengaruh Shopping Lifestyle dan Positive Emotion terhadap Impulse Buying baik secara parsial maupun simultan. Perhitungan koefisien determinasi antara variabel menggunakan SPSS 21 dapat dilihat pada tabel berikut:

\section{Tabel 11}

Hasil Koefisien Determinasi

Coefficients $^{\mathrm{a}}$

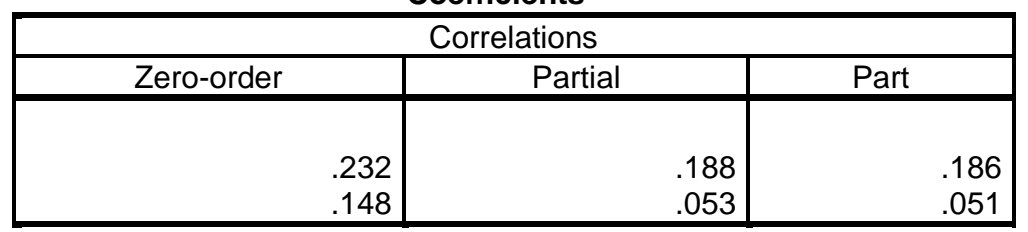

a. Dependent Variable: impulse buying

a. Koefisien determinasi Shopping

Lifestyle terhadap Impulse Buying:

$$
\begin{aligned}
\mathrm{KD} & =r^{2} \times 100 \% \\
& =0,232^{2} \times 100 \% \\
& =53,82 \%
\end{aligned}
$$

Besarnya kontribusi Shopping Lifestyle mempengaruhi Impulse Buying yaitu sebesar 53,82\%. b. Koefisien determinasi Positive Emotion terhadap Impulse Buying:

$$
\begin{aligned}
\mathrm{KD} & =\mathrm{r}^{2} \times 100 \% \\
& =0,148^{2} \times 100 \% \\
& =21,90 \%
\end{aligned}
$$

Besarnya kontribusi Positive Emotion mempengaruhi Impulse Buying yaitu sebesar $21,90 \%$

Tabel 12

Hasil Koefisien Determinasi Model Summary ${ }^{b}$

\begin{tabular}{|l|r|r|r|r|r|}
\hline Model & R & R Square & Adjusted R Square & $\begin{array}{c}\text { Std. Error } \\
\text { of the } \\
\text { Estimate }\end{array}$ & Durbin-Watson \\
& $.437^{\mathrm{a}}$ & .190 & .144 & 9.80103 & 1.989 \\
\hline 1 & .1903 &
\end{tabular}




\section{ENTREPRENEUR}

\section{Jurnal Bisnis Manajemen Dan Kewirausahaan}

Program Studi Manajemen Fakultas Ekonomika dan Bisnis Universitas Majalengka Published every January and July e-ISSN : (Proses), p-ISSN: 2723-1941 Available online https://ejournal.unma.ac.id/index.php/entrepreneur

a. Predictors: (Constant), Positive Emotion, Shopping Lifestyle

b. Dependent Variable: Impulse Buying

c. Koefisien determinasi Shopping Lifestyle dan Positive Emotion terhadap Impulse Buying:

$$
\begin{aligned}
\mathrm{KD} & =\mathrm{R}^{2} \times 100 \% \\
& =0,437^{2} \times 100 \% \\
& =19,09 \%
\end{aligned}
$$

Besarnya kontribusi Shopping Lifestyle dan Positive Emotion mempengaruhi Impulse Buying yaitu sebesar $19,09 \%$ dan sisanya 80,91 $(100 \%-19,09 \%)$ ditentukan oleh variabel lain yang tidak diteliti.

\section{Uji Hipotesis}

\section{Uji Parsial}

Berdasarkan tabel 10 dapat diperoleh nilai $t_{\text {hitung }}$ dari variabel Shopping Lifestyle 2,320. Dengan menggunakan tingkat signifikan 5\% dan nilai df sebesar $\mathrm{n}-2$ (150-2) - 148 diperoleh nilai $t_{\text {tabel }}$ sebesar 1.655 maka Ho ditolak, artinya Shopping Lifestyle berpengaruh signifikan Impulse Buying. Karena $t_{\text {hitung }} 2,320>1,655$ maka Ho ditolak, artinya Shopping Lifestyle berpengaruh signifikan Impulse Buying.

Berdasarkan tabel 10 dapat diperoleh nilai $t_{\text {hitung dari variabel }}$ Positive Emotion sebesar 2,639. Dengan menggunakan tingkat signifikansi 5\% dan nilai df sebesar n-2 (150 -2) - 148 diperoleh nilai $t_{\text {tabel }}$ sebesar 1,655. Karena $t_{\text {hitung }} 2,639>t_{\text {tabel }} 1,655$ maka Ho ditolak, artinya Positive Emotion berpengaruh signifikan terhadap Impulse Buying.

\section{Uji Secara Simultan}

Tabel 13

Hasil Uji Simultan

ANOVA $^{\mathrm{a}}$

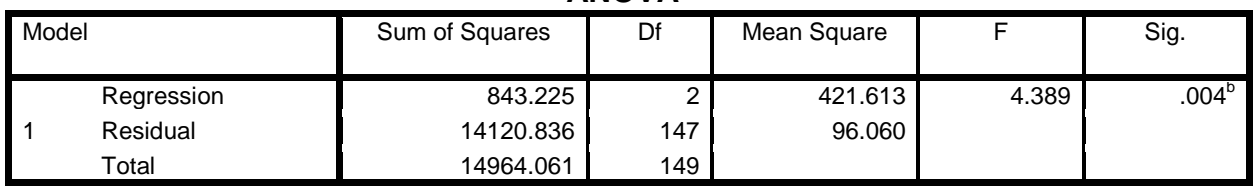

a. Dependent Variable: Impulse Buying

b. Predictors: (Constant), Positive Emotion, Shopping Lifestyle

Sumber : Output SPSS Versi 21, 2018 


\section{ENTREPRENEUR}

\section{Jurnal Bisnis Manajemen Dan Kewirausahaan}

Program Studi Manajemen Fakultas Ekonomika dan Bisnis Universitas Majalengka

Published every January and July e-ISSN : (Proses), p-ISSN: 2723-1941

Available online https://ejournal.unma.ac.id/index.php/entrepreneur

Dengan perhitungan uji $\mathrm{F}$ menggunakan SPSS versi 21, dengan nilai profitabilitas $(\mathrm{sig})=0,004$ sedangkan nilai $F_{\text {tabel }}$ pada taraf signifikan $5 \%(\mathrm{dk})=\mathrm{n}-1-\mathrm{k}=150-1-2=147$ pada tabel $\mathrm{F}$ untuk dk 147, diperoleh $\mathrm{F}_{\text {tabel }}$ sebesar 3,06. Karena $F_{\text {hitung }}=4,389>$ $F_{\text {tabel }}$ 3,06 maka Ho ditolak, artinya Shopping Lifestyle dan Positive Emotion berpengaruh positif dan signifikan terhadap Impulse Buying. Dengan demikian dapat disimpulkan bahwa hipotesis pada penelitian ini dapat dibuktikan kebenarannya.

\section{Pengaruh Shopping LIfestyle terhadap Impulse Buying UD Putra Tiga Saudara Majalengka}

Berdasarkan hasil uji secara parsial dengan menggunakan uji $t$ terdapat pengaruh yang signifikan antara shopping lifestyle terhadap impulse buying. Artinya gaya berbelanja menjadi factor pendorong dalam meningkatnya perilaku pemeblian yang tidak terencana sebelumnya yang dilakukan oleh konsumen UD Putra Tiga Saudara Majalengka

Hasil penelitian ini telah di dukung dengan penelitian yang dilakukan oleh Mega Usvita (2015:74) yang menyatakan bahwa shopping lifestyle berpengaruh positif dan signifikan terhadap impulse buying, yang menyampaikan secara spesifik shopping lifestyle memiliki pengaruh yang paling dominan terhadap impulse buying. Hal ini bermakna bahwa shopping lifestyle lebih besar pengaruhnya karena sebab gaya hidup seseorang saat berbelanja dapat dijadikan salah satu faktor penting untuk produsen dalam meningkatkan produknya melalui terbentuknya pembelian yang didorong perilaku yang berhubungan dengan panca indera, khayalan dan emosi yang menjadikan kesenangan dan kenikmatan sehingga menimbulkan pembelian impulsif sebagai hasil dari suatu pertimbangan atau niat membeli yang terbentuk sebelum masuk ke UD Putra Tiga Saudara Majalengka.

\section{Pengaruh Positive Emotion terhadap Impulse Buying UD Putra Tiga \\ Saudara}

Majalengka

Berdasarkan hasil uji secara parsial terdapat pengaruh yang signifikan antara positive emotion terhadap impulse buying. Artinya emosi yang positif yang dimiliki oleh konsumen UD Putra Tiga Saudara Majalengka mampu meningkatkan keinginan berbelanja yang tidak terencana sebelumnya

Hasil penelitian ini menunjukkan bahwa variabel positive emotion mendukung pendapat Shoham dan Brencic (2003) dalam penelitiannya yang mengatakan bahwa pembelian impulsif berkaitan dengan perilaku untuk membeli berdasarkan emosi. Emosi ini berkaitan dengan pemecahan masalah pembelian yang terbatas atau spontan. Konsumen melakukan pembelian tanpa berfikir panjang untuk apa kegunaan barang yang mereka beli, yang penting mereka terpuaskan. Artinya emosi merupakan hal yang utama digunakan sebagai suatu dasar pembelian suatu produk.

\section{Pengaruh Shopping Lifestyle dan Positive Emotion terhadap Impulse Buying UD Putra Tiga Saudara Majalengka \\ Berdasarkan hasil uji secara} simultan shopping lifestyle dan positive emotion berpengaruh positif dan signifikan terhadap impulse buying. Artinya gaya berbelanja yang diikuti dengan emosi positif dari konsumen 


\section{ENTREPRENEUR}

\section{Jurnal Bisnis Manajemen Dan Kewirausahaan}

Program Studi Manajemen Fakultas Ekonomika dan Bisnis Universitas Majalengka

Published every January and July e-ISSN : (Proses), p-ISSN: 2723-1941

Available online https://ejournal.unma.ac.id/index.php/entrepreneur

mampu meningkatkan keinginan

berbelanja yang lebih karena tidak terencana sebelumnya.

Shopping lifestyle dan positive emotion mempunyai pengaruh yang signifikan terhadap impulse buying pada UD Putra Tiga Saudara Majalengka. Artinya ketika shopping lifestyle dan positive emotion meningkat maka impulse buying pun akan meningkat. Hasil penelitian ini mendukung pendapat Mega Usvita (2015) yang menyatakan bahwa secara simultan terdapat pengaruh shopping lifestyle dan positive emotion terhadap impulse buying. Munculnya mood konsumen untuk berbelanja dengan melihat ketertarikannya pada produk, kondisi lingkungan dan promosi penjualan yang menarik sehingga menimbulkan impulse buying di Plaza Andalas Padang.

\section{KESIMPULAN DAN IMPLIKASI Kesimpulan}

Berdasarkan hasil penelitian yang telah dilakukan peneliti pada konsumen UD Putra Tiga Saudara Majalengka mengenai shopping lifestyle dan positive emotion terhadap impulse buying, serta melihat hasil analisi data, maka peneliti mengambil kesimpulan sebagai berikut:

1. Shopping lifestyle berpengaruh secara signifikan terhadap impulse buying. Artinya semakin tinggi gaya hidup berbelanja konsumen maka pembelian impulsif semakin banyak dilakukan, dan semakin rendah gaya hidup berbelanja konsumen maka pembelian impulsif semakin jarang dilakukan.

2. Positive emotion berpengaruh secara signifikan terhadap impulse buying. Artinya semakin konsumen merasa senang, nyaman dan bergairah ketika berbelanja maka konsumen semakin mudah melakukan pembelian impulsif, dan semakin konsumen merasa tidak senang, tidak nyaman, dan tidak bergairah ketika bebelanja maka pembelian impulsif sulit terjadi.

3. Secara simultan dan positive emotion berpengaruh secara signifikan terhadap impulse buying. Artinya ketika gaya hidup berbelanja konsumen tinggi dan konsumen merasa nyaman, senang atau dalam mood yang baik maka pembelian impulsif mudah terjadi. Sebaliknya, ketika gaya hidup berbelanja konsumen rendah ditambah konsumen dalam suasana hati yang tidak baik dan tidak nyaman maka pembelian impulsif sulit terjadi.

\section{IMPLIKASI}

Berdasarkan kesimpulan hasil penelitian yang diperoleh di atas, maka beberapa saran yang dapat diberikan bahan masukan untuk pihak perusahaan adalah sebagai berikut:

1. Pihak manajemen UD Putra Tiga Saudara Majalengka harus lebih memperbanyak diskon (promo untuk menarik konsumen agar lebih meluangkan waktunya melakukan pembelian.

2. Pihak manajemen Toko UD Putra Tiga Saudara Majalengka harus memberikan SPG untuk menarik rangsangan konsumen melakukan pembelian.

3. Pihak manajemen UD Putra Tiga Saudara Majalengka harus lebih memaksimalkan kualitas produk, harga, suasana toko dan fasilitas agar tertarik dan nyaman untuk berbelanja. 


\section{ENTREPRENEUR}

\section{Jurnal Bisnis Manajemen Dan Kewirausahaan}

Program Studi Manajemen Fakultas Ekonomika dan Bisnis Universitas Majalengka Published every January and July e-ISSN : (Proses), p-ISSN: 2723-1941 Available online https://ejournal.unma.ac.id/index.php/entrepreneur

\section{Daftar Pustaka}

A.A. Anwar, Prabu Mangkunegara. 2009. Perilaku Konsumen. Bandung: Refika Anggi M. Wijaya, Moh. Hufron dan A. R. Slamet. 2016. Pengaruh Shopping Lifestyle dan Fashion Involvement Terhadap Impulse Buying (Studi Kasus Pembelian Hijab Pada Mahasiswi Fakultas Ekonomi Universitas Islam Malang). E - jurnal Riset Manajemen Prodi Manajemen Fakultas Ekonomi Unisma.

Bayley, G, \& Nancarrow, C. 1998. Impulse purchas-ing: a qualitative exploration pf the phenol-menon. Qualitative market research: An Inter-national Journail, 1(2), pp. 99-114.

Edwin Japariyanto dan Sugiono Sugiharto. 2011. Pengaruh Shopping Lifestyle dan Fashion Involvement Terhadap Impulse Buying Behavior Masyarakat Hight Income Surabaya. Jurnal Manajemen Pemasaran, Vol. 6, No. 1, April 2011 : 32-41.

Japariyanto. E \& Sugiyono Sugiharto. 2011. Pengaruh Shopping Lifestyle dan Fashion Involvement Terhadap Impulse Buying Behavior Masyarakat Hight Income Kota Surabaya. Jurnal Manajemen Pemasaran Vol 6 no.1 32-41 Kim. 2005.

Mega Usvita. 2015. Pengaruh Hedonic Shopping Value, Shopping Lifestyle dan Positive Emotion Terhadap Impulse Buying Pada Plaza Andalas Padang. E - Jurnal
Apresiasi Ekonomi Volume 4, Nomor 1, Januari 2016 : 71-75.

Meniawy. A. M. E. 2012. Personal Characteristic and situational influences affecting consumers adoption of impulse buying behavior. International conference on business and economic research. Retrieved October 1, 2013, from http://www.internationalconferenc e.com.my.

Park, E.J., Eun, Y.K., Judith, C.F. 2006. A Structural Model of FashionOriented Impulse Buying Behavior. Journal pf Fashion Marketing and Management. 10(4), pp. 433-446.

Pattipeilohy. V. R. Rofiaty \& Idrus M. S. 2013. The Influence of the availability of Money and Time, Fashion Involvement, Hedonic Consumption Tendency and Positive Emotions towards Impulse Buying Behavior in Ambon City (Study on Purchasing Products Fashion Apparel). International Journal of Business and Behavioral Sciences Vol. 3, No. 8; August 2013.

Rook, D. W. dan Gardner, M. P. 1993. In The Mood: Impulse Buying's affective antecedents. Research in Consumer Behavior. Vol. 6. PP 126.

Sinai Ariani. 2017. Pengaruh Shopping Lifestyle dan Emosi Positif Terhadap Impulse Buying (Studi Kasus Pada Konsumen Yogya 
Entrepreneur : Jurnal Bisnis Manajemen dan Kewirausahaan, Volume 1 Nomor 1, Januari 2020

\section{ENTREPRENEUR}

\section{Jurnal Bisnis Manajemen Dan Kewirausahaan}

Program Studi Manajemen Fakultas Ekonomika dan Bisnis Universitas Majalengka Published every January and July e-ISSN : (Proses), p-ISSN: 2723-1941

Available online https://ejournal.unma.ac.id/index.php/entrepreneur

Grand Majalengka). Skripsi.

Universitas Majalengka.

Sugiyono. 2015. Metode Penelitian \&

Pengembangan (Research and

Development). Bandung.

Alfabeta. 